\title{
The Use of Bacteriophages in the Poultry Industry
}

\author{
Katarzyna Żbikowska ${ }^{1}$, Monika Michalczuk ${ }^{1}$ and Beata Dolka ${ }^{2, *} \mathbb{1}$ \\ 1 Department of Animal Breeding, Institute of Animal Sciences, Warsaw University of Life Sciences-SGGW, \\ Ciszewskiego 8 St., 02-786 Warsaw, Poland; katarzyna.zbikowska@fermydrobiubebnowo.pl (K.Ż.); \\ monika_michalczuk@sggw.edu.pl (M.M.) \\ 2 Department of Pathology and Veterinary Diagnostics, Institute of Veterinary Medicine, \\ Warsaw University of Life Sciences-SGGW, Nowoursynowska 159c St., 02-776 Warsaw, Poland \\ * Correspondence: beata_dolka@sggw.edu.pl
}

Received: 19 April 2020; Accepted: 16 May 2020; Published: 18 May 2020

check for updates

Simple Summary: Poultry production is one of the worldwide sectors which utilizes many antibiotics. Reducing antibiotic use is one of the biggest challenges to the poultry industry globally. Due to the increasing risk of antibiotic-resistant bacteria, the European Union has in 2006 imposed a ban on the use of antibiotics as growth promoters in food-producing animals, but they are still used in other parts of the world. Following the ban, many countries reported a negative impact on animals' well-being, the re-emergence of old infectious diseases in poultry, and an increase in the usage of antibiotics in poultry for therapeutic purposes. Nowadays, foodborne bacterial pathogens have been considered as the leading bacterial causes of human diseases. In the era of the increasing emergence of multidrug-resistant bacteria and a lack of new effective antibiotics, it is natural that much scientific effort has been put into developing and implementing new technologies to combat bacteria. In this context, bacteriophages (phages) have been proposed as an alternative strategy to antibiotics for poultry, and thus for food safety and public health.

\begin{abstract}
The emergence of multidrug-resistant infections and antibiotic failures have raised concerns over human and veterinary medicine worldwide. Poultry production has had to confront the problems of an alarming increase in bacterial resistance, including zoonotic pathogens. According to the European Food Safety Authority (EFSA), campylobacteriosis and salmonellosis have been the most frequently reported human foodborne diseases linked to poultry. This situation has strongly stimulated a renewal of scientists' interest in bacteriophages (phages) since the beginning of the 21st century. Bacteriophages are the viruses of bacteria. They are abundant in nature, and accompany bacteria in each environment they colonize, including human microbiota. In this review, we focused on the use of bacteriophages as therapeutic agents to treat infections and reduce counts of pathogenic bacteria in poultry, as biocontrol agents to eliminate foodborne pathogens on/in food, and also as disinfectants to reduce contamination on food-contact surfaces or poultry carcasses in industrial conditions. Most of the phage-based products are targeted against the main foodborne pathogens, such as Campylobacter jejuni, Salmonella spp., Escherichia coli, Listeria monocytogenes, Staphylococcus aureus, and Clostridium perfringens. Phages are currently addressed at all stages of the poultry production "from farm to fork", however, their implementation into live birds and food products still provokes discussions especially in the context of the current legal framework, limitations, as well as public health and safety.
\end{abstract}

Keywords: bacteriophages; poultry; phage therapy; food safety; disinfection; multidrug-resistant bacteria; foodborne diseases 


\section{Introduction}

Bacteriophages (phages, BPs) are viruses that specifically target and infect prokaryotes (bacteria) or arachea. Bacteriophages were discovered independently by two scientists: Frederick Twort (in 1915) and Felix d'Herelle (in 1917) [1-3]. They are globally ubiquitous, with an estimated total number of phage particles in the biosphere approximating $10^{31}$, which is 10 -times more than the estimated number of bacterial cells on the Earth [4]. Bacteriophages are considered as being non-pathogenic to humans. They can be found in all habitats colonized by bacteria, including water, plants, and food, and therefore are frequently consumed by people. Moreover, phages have been recognized as important components of the natural microbiome of humans. The human gut virome (the whole viral community in gut) is predominated by bacteriophage community (known as the phageome). However, little is known about the healthy chicken gut phageome still [5].

Phages are categorized based on their morphology (three-dimensional shaped, pleomorphic, polyhedral, icosahedral, filamentous, head-tail or thread-like shaped), nucleic acid (+ ssRNA, dsRNA, ssDNA, dsDNA), phage life cycle, bacterial target and site. Over 5000 phages have been examined by the electron microscopy, and most of them (96\%) had tails. Bacteriophages are classified into many orders and 15 families. The tailed phages constitute the order Caudovirales, which is divided into families: Siphoviridae (61\% of tailed phages), Myoviridae (25\%), and Podoviridae (14\%) families [6]. The vast majority of phages belong to the order Caudovirales and have a broad range of isometric heads varying from 20 to $200 \mathrm{~nm}$ [7] which makes them 1000 times smaller than the average bacterium (0.5-20 $\mu \mathrm{m})$.

Bacteriophages are obligate parasites of bacteria, using the bacterial cell to replicate. Depending on their interactions with bacteria and their life cycle, they are divided into two types: lytic (virulent, productive) and lysogenic (temperate, dormant) (Figure 1). Certain bacteriophages have the ability to perform both lytic and lysogenic cycles (e.g., phage lambda of Escherichia coli). During the lytic cycle, a bacteriophage infects a target bacterium (live bacterial target cell), replicates therein, kills the bacterium by lysis, and releases multiple (20-200) [8] or hundreds to thousands of phages [9]. In detail, at the end of the lytic cycle, the phage protein (holin) makes pores within the cytoplasmic membrane and thus enables the phage-encoded endolysin (called 'lysin') to gain access and hydrolyze the peptidoglycan layer. This results in cell lysis and release of the progeny phages (produced by the host bacterium), which can infect other bacterial cells, thereby repeating the cycle [9]. The duration of the whole cycle may vary and is usually within $20-40 \mathrm{~min}$ to $1-2 \mathrm{~h}$. Lytic phages have several potential applications.

In contrast, the lysogenic cycle does not result in the lysis of the host cell and progeny production. Instead, it leads to the integration of phage genetic material into the bacterial genome, and its, transmission into new cells (after cell division). The dormant phage is known as a prophage or endogenous phage (a latent form of phage). Under abnormal environmental conditions, the phage can become active and enter the lytic stage [10,11] (Figure 1).

Phages show specificity for various bacteria. Monovalent phages are specific to one type of bacterial species but polyvalent phages are able to attack different (two or more) bacterial species. Most works have indicated that bacteriophages targeting Gram-positive bacteria are not simultaneously effective against the Gram-negatives. Bacteriophages encode endolysins (phage lysins, hydrolases) which are involved in lysis of bacterial cell wall (peptidoglycan layer) from the inside at the end of replication (lytic cycle) thus resulting in release of the viral progeny phages. Moreover, bacteriophage endolysins can destroy the peptidoglycan layer when applied externally to the bacterial cell, and hence may play a role as novel antimicrobial agent. Exogenous activity of endolysins is particularly effective against Gram-positive bacteria, since they lack an outer membrane, unlike the Gram-negatives. Gram-negative bacteria are difficult to lyse because the outer membrane blocks access of endolysin to peptidoglycan. Endolysin-mediated external lysis of Gram-negative bacteria can be achieved; however through the use of a permeabilizing agent [12]. On the one hand, the selective ability of phages to 
attack certain bacteria allows for the selective elimination of pathogenic bacteria, but on the other hand restricts their use for therapeutic purposes.
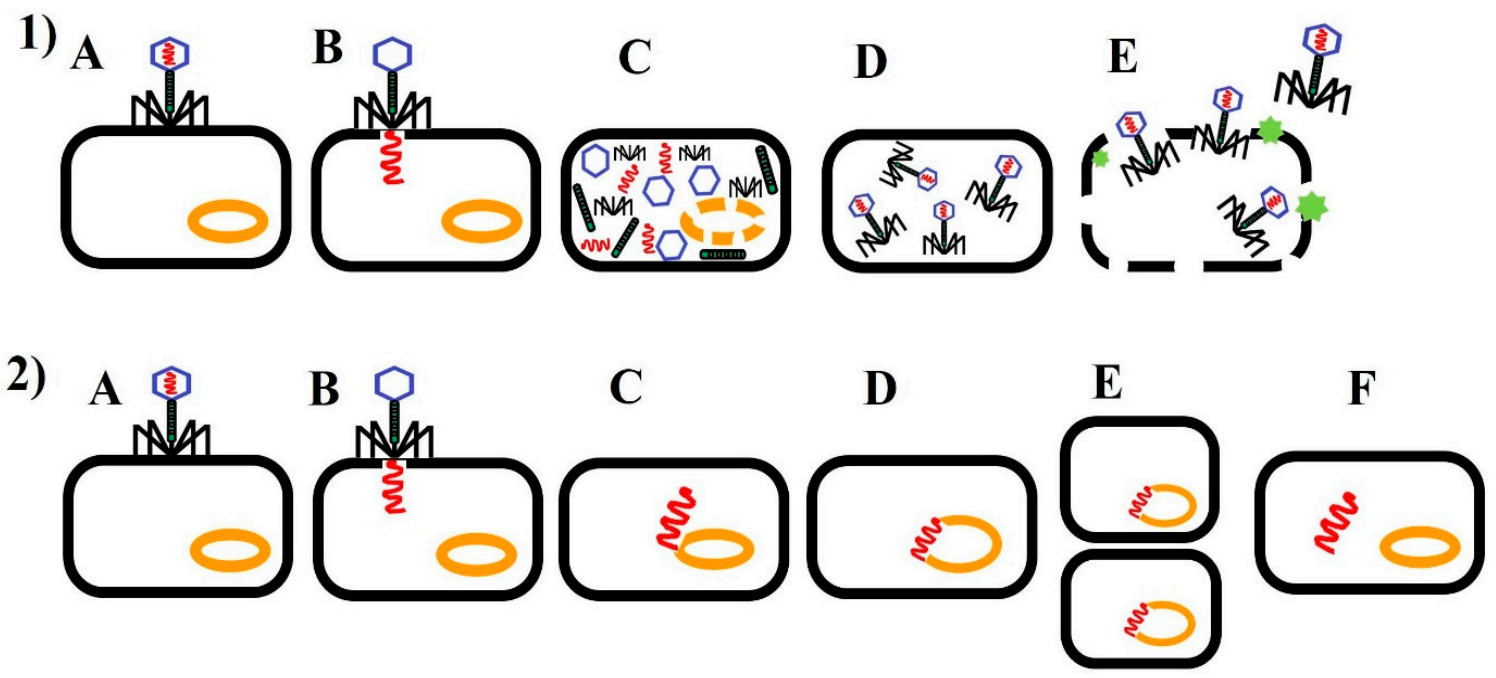

Figure 1. Life cycle of bacteriophage. (1) Lytic cycle. (A) Attachment: the phage binds to a receptor on the bacterial cell surface. (B) Penetration: the phage inserts its DNA into the bacterial cytoplasm. (C) DNA replication and protein synthesis: the phage takes over the bacterial cell functions and directs the synthesis to produce of phage DNA copies and proteins. Bacterial DNA is degraded. (D) Assembly packaging: new phage particles are assembled within host cell. (E) Lysis: the phage produces an enzyme which destroys the bacterial cell wall, causing lysis and the release new phages. The bacterial host cell is destroyed. Progeny phages can infect further bacterial cells and the cycle starts again. (2) Lysogenic cycle. (A) Attachment: the phage binds to a receptor on the bacterial cell surface. (B) Penetration: the entry of phage nucleic acid. (C) Integration of phage DNA: the phage DNA then moves through the cytoplasm to the host bacterial DNA and integrates itself into the host genome. (D) Prophage stage: the phage DNA is incorporated into the bacterial genome and becomes a (noninfective) prophage. (E) The prophage is replicated along with the bacterial genome. The bacterial cell divides and prophage DNA is transferred into daughter cells. (F) Sometimes the prophage can be induced to become active. The prophage DNA is excised from the bacterial genome and enters the lytic cycle.

In the past decades, the emergence of multidrug antibiotic-resistant bacteria (MDR) has been reported as a result of too common and frequent use of antibiotics in human and veterinary medicine as well as in industry and agriculture. Moreover, MDR can be transmitted from food-producing animals to humans via direct contact between animals and humans, or through the food chain and the environment $[13,14]$. In the face of a loss of life-saving antibiotics and the lack of new ones, researchers have started the search for alternative means of fighting bacterial pathogens, such as vaccines, probiotics, prebiotics, bacteriophages, nanoparticles, antimicrobial peptides (AMPs), or anti-virulence compounds. There has been an explosion of research and interest in the usage of bacteriophages in the poultry veterinary medicine and the poultry industry. Thus, in turn, new companies developing bacteriophage preparations have appeared on the global market. Examples of phage applications in poultry farming, processing, and production are shown in Figure 2. 


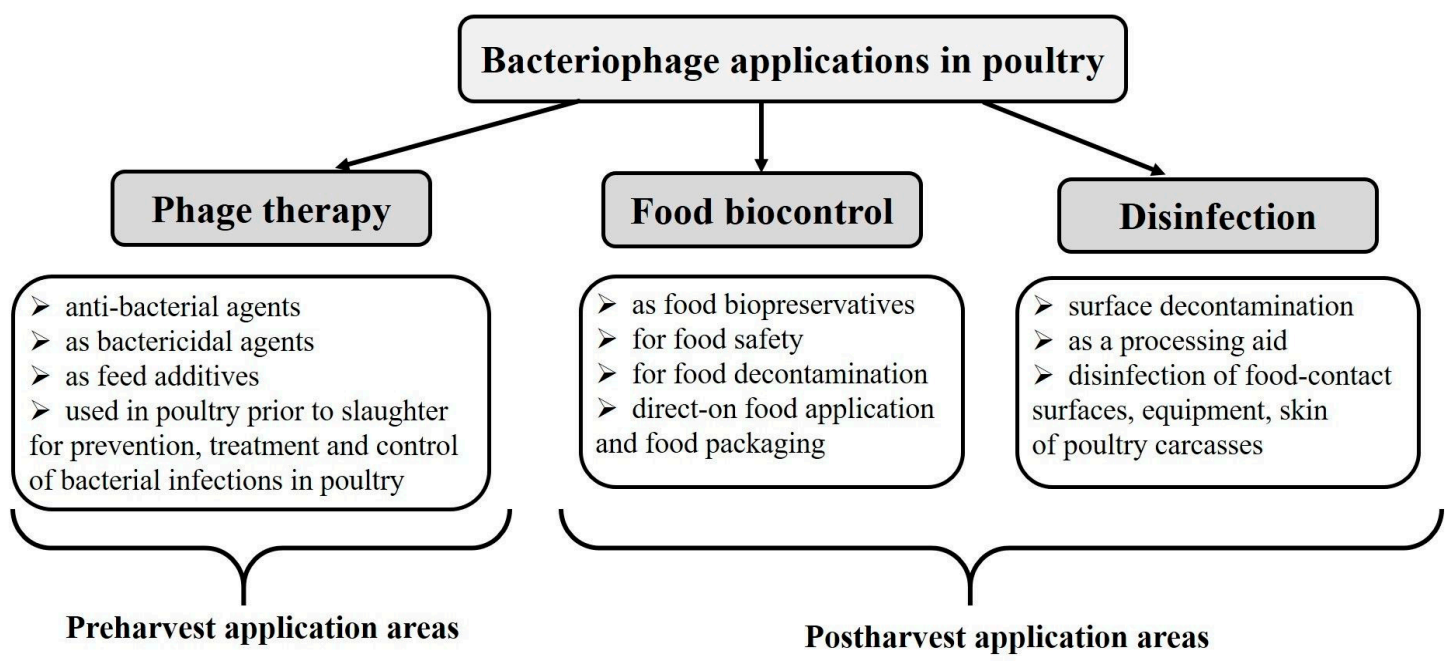

Figure 2. Examples of phage application in the poultry industry.

\section{Phage Therapy of Bacterial Infections in Poultry}

Public health concerns have increased the attention paid to pathogen, such as Camylobacter jejuni (C. jejuni), Salmonella enterica subspecies enterica serovar Enteritidis (S. Enteritidis), Salmonella enterica subspecies enterica serovar Typhimurium (S. Typhimurium), Eschericha coli (E. coli), Listeria monocytogenes (L. monocytogenes), and methicillin-resistant Staphylococcus aureus (MRSA), because of the risk posed by poultry as a source of these pathogens. Most works have addressed the efficacy of bacteriophages in reducing bacterial count and in the control of bacterial infections in poultry, which are zoonotic and have a substantial impact on public health [15-17]. According to a recent report of the European Food Safety Authority (EFSA) and the European Centre for Disease Prevention and Control (ECDC) (2019), campylobacteriosis followed by salmonellosis, Shiga toxin-producing E. coli (STEC) infection, and yersiniosis were the most frequently reported zoonoses in the European Union (EU) [18]. Due to their restricted ability to kill bacteria, only the lytic bacteriophages are suitable for phage therapy applied to treat bacterial infections. Bacteriophages are much more specific than antibiotics are. It should be noted that antibiotic treatment not only kills the pathogenic bacteria but also affects the normal intestinal microbiota, potentially leading to dysbiosis, immunosuppression, and thus to secondary infections [14]. Hence, novel bacteriophage treatments, represent an excellent tool for the treatment of bacterial infections in poultry. Table 1 shows examples of commercial bacteriophage products. 
Table 1. Bacteriophage products addressed to the poultry industry.

\begin{tabular}{|c|c|c|c|c|c|}
\hline Target Bacteria & Product Name & Manufacturer & Bacteriophages & Notes & Ref. \\
\hline Salmonella & Bafasal $^{\circledR}$ & Proteon Pharmaceuticals (Éd́dź, Poland) & $\begin{array}{l}3 \text { phages: 3ent1, } 8 \text { sent65 and } 8 \text { sent1748, mixed in } \\
\text { equal concentration }\end{array}$ & $\begin{array}{l}\text { - } \text { regulatory-approved feed additive } \\
\text { for use in poultry to eliminate or prevent Salmonella } \\
\text { infection in the digestive tract in poultry } \\
\text { can be added to drinking water }\end{array}$ & {$[19,20]$} \\
\hline $\begin{array}{l}\text { Salmonella Gallinarum, } \\
\text { Salmonella Pullorum }\end{array}$ & Biotector ${ }^{\circledR} \mathrm{S}$ & $\begin{array}{l}\text { CJ Cheilledang Research Institute of } \\
\text { Biotechnology (Seoul, South Korea) }\end{array}$ & nd & $\begin{array}{l}\text { - can be applied on animal feed to control Salmonella } \\
\text { in poultry }\end{array}$ & [21] \\
\hline Salmonella enterica & SalmoFresh ${ }^{\mathrm{TM}}$ & Intralytix Inc. (Columbia, MD, USA) & 6 lytic phages & $\begin{array}{l}\text { - } \quad \text { for treating food } \\
\text { - FDA-approved, granted GRAS status }\end{array}$ & {$[15,21]$} \\
\hline Salmonella enterica & SalmoPro® ${ }^{\circledR}$ & Phagelux (Montreal, QC, Canada) & 2 phages: BP- $63, \mathrm{BP}-12$ & $\begin{array}{l}\text { - for use as an antimicrobial processing aid to control } \\
\text { Salmonella on food, when applied onto food surfaces } \\
\text { up to } 10^{8} \mathrm{PFU} / \mathrm{g} \text { of food } \\
\text { - FDA-approved, granted GRAS status }\end{array}$ & {$[15,21,22]$} \\
\hline Salmonella & Salmonelex ${ }^{\mathrm{TM}}$ (PhageGuard) & $\begin{array}{l}\text { Micreos Food Safety BV (The } \\
\text { Netherlands) }\end{array}$ & 2 phages & $\begin{array}{l}\text { - for use as an antimicrobial on foodstuffs to control } \\
\text { Salmonella at an application rate of up to } 10^{8} \mathrm{PFU} / \mathrm{g} \\
\text { of food } \\
\text { can be sprayed topically or added to chill tank water } \\
\text { - FDA-approved, granted GRAS status }\end{array}$ & [23] \\
\hline Salmonella & PhageGuard S ${ }^{\mathrm{TM}}$ & $\begin{array}{l}\text { Micreos Food Safety BV (Wageningen, } \\
\text { The Netherlands) }\end{array}$ & 2 phages: Fola and S16 & $\begin{array}{l}\text { - } \quad \text { ater-based phage solution } \\
\text { - } \quad \text { tan be applied by spraying, dipping, immersion } \\
\text { - can be applied on fresh poultry or meat pre-grinding } \\
\text { or pre-packaging } \\
\text { - } \quad \text { for decontamination of surfaces } \\
\text { FDA-approved, granted GRAS status }\end{array}$ & {$[15,24]$} \\
\hline Salmonella & $\mathrm{BacWash}^{\mathrm{TM}}$ & OmniLytics Inc. (Sandy, UT, USA) & nd & - for disinfection of surfaces & [25] \\
\hline Salmonella & SalmoFREE ${ }^{\circledR}$ & Sciphage (Bogotá, Colombia) & 6 lytic phages & - for therapy and control Salmonella in poultry farm & {$[26,27]$} \\
\hline Escherichia coli O157:H7 & EcoShield $^{\mathrm{TM}}$ & Intralytix Inc. (Columbia, MD, USA) & $\begin{array}{l}\text { 3lytic phages: ECML-4, ECML-117, ECML-134 in the } \\
\text { Myoviridae family isolated from the environment } 10^{10} \\
\text { PFU } / \mathrm{mL} \text { in PBS, pH } 7.4\end{array}$ & $\begin{array}{l}\text { - } \quad \text { for treating food } \\
\text { FDA-approved, granted GRAS status }\end{array}$ & {$[15,28]$} \\
\hline
\end{tabular}


Table 1. Cont.

\begin{tabular}{|c|c|c|c|c|c|}
\hline Target Bacteria & Product Name & Manufacturer & Bacteriophages & Notes & Ref. \\
\hline $\begin{array}{l}\text { Escherichia coli } \\
\text { O157:H7 }\end{array}$ & Ecolicide PX'⿳一 & Intralytix Inc. (Columbia, MD, USA) & nd & $\begin{array}{l}\text { - for pre-harvest interventions } \\
\text { applied on hides of live animals } \\
\text { for reducing contamination prior to animal entering } \\
\text { processing facility }\end{array}$ & [21] \\
\hline Listeria monocytogenes & ListShield $^{\mathrm{TM}}$ & Intralytix Inc. (Columbia, MD, USA) & $\begin{array}{l}6 \text { phages: LIST-36, LMSP-25, LMTA-34, LMTA-57, } \\
\text { LMTA-94, LMTA-148 }\end{array}$ & $\begin{array}{l}\text { - } \quad \text { food biopreservative } \\
\text { - } \quad \text { for treating food } \\
\text { - } \quad \text { FDA-as approod processing aid granted GRAS status }\end{array}$ & {$[15,28,29]$} \\
\hline Listeria monocytogenes & Listex ${ }^{\mathrm{TM}}$ P100 (PhageGuard) & $\begin{array}{l}\text { Micreos Food Safety BV. (Wageningen } \\
\text { The Netherlands) }\end{array}$ & Phage P100 & $\begin{array}{l}\text { - applied by spraying or dipping } \\
\text { - } \text { food biopreservative } \\
\text { and food Listeria contamination on food products } \\
\text { - can be applied on RTE meatities. } \\
\text { FDA-approved, granted GRAS status }\end{array}$ & {$[15,25,30-32]$} \\
\hline
\end{tabular}

FDA (U.S. Food and Drug Administration); GRAS (generally recognized as safe); PFU (plaque forming units); RTE (ready-to-eat); nd (no data). 


\subsection{Campylobacter}

Campylobacter spp. bacteria are ubiquitous in various environments but prefer the gut of birds, which they colonize as commensals. Due to the conducive (optimal) body temperature, poultry has become a natural reservoir for Campylobacter species, representing the major source of human infections. Campylobacter spp. colonization in chickens takes place at poultry farms, approximately seven days after hatching. Although chickens are carriers of Campylobacter, they typically do not exhibit clinical signs or lesions. The prevalence of Campylobacter spp. in poultry flocks varies considerably from $2 \%$ to $100 \%$ [33]. Study results have indicated the high prevalence of Campylobacter in poultry at slaughter, where $100 \%$ of small intestinal samples and $91.5 \%$ of swabs from carcass surfaces were positive [34]. Other authors noted lower prevalence in broiler chickens (34.3\%, cecum samples) [35]. According to EFSA and ECDC report, the prevalence of Campylobacter spp. was $71.6 \%$ in turkeys and $26 \%$ in broilers in 2018 [18]. Two species have been reported to prevail in poultry: C. jejuni (86.1\% or 64.6\%) and C. coli. (13.9\% or 35.4\%) [34,35]. Similarly, at a farm level, the prevalence of C. jejuni $(65.8 \%)$ was significantly higher than that of $C$. coli $(12.6 \%)$ [36]. The persistent presence of Campylobacter contaminating the environment in slaughterhouses and poultry products has been reported worldwide. According to EFSA and ECDC, the highest prevalence of Campylobacter was observed in fresh meat from broilers $(37.5 \%)$ followed by fresh meat from turkeys (28.2\%) [18]. In addition, the increasing number of reports regarding Campylobacter antibiotic resistance (to fluoroquinolones, tetracycline, erythromycin, gentamicin) and virulence are moving forward the efforts to reduce Campylobacter [34-36]. Generally, the occurrence of bacteriophages specific to Campylobacter among commercial poultry or retail chicken products is low, and most of them belong to the family Myoviridae, rarely to Siphoviridae [35,37,38]. Recent experimental studies have provided evidence for the efficacy of phage treatment in reducing the Campylobacter colonization in chickens and thus in minimizing the risk of its entrance into the food chain. A phage cocktail containing virulent Campylobacter phages was used by oral route to treat broiler chickens colonized with $C$. jejuni. Bacteriophage predation of $C$. jejuni did not affect the microbiota but selectively reduced the abundance of $C$. jejuni. Authors have concluded that bacteriophage control to reduce $C$. jejuni levels in chickens could reduce human exposure and disease acquired through the consumption of contaminated poultry products [39]. Despite the obvious need for implementing novel solutions aimed to reduce the rate of infections induced by Campylobacter spp., there are still not available commercial phage products against these bacteria. This can be due to the fact that, compared with most other lytic phages, Campylobacter phages exhibit some characteristics which make their application rather difficult. The problems with the production of safe Campylobacter phage cocktails are associated mainly with the optimization methods for phages isolation, propagation and purification. Moreover, there are differences between Campylobacter phages within groups (i.a. in host range, lytic activity, kinetics), even they are genetically very similar, which make difficulties with appropriate selection of phage candidates for application. In addition, the emergence of phage resistant Campylobacter post-phage treatment have been reported (the frequency of 1-14\%). Finally, the cost of production is also the next major consideration $[39,40]$.

\subsection{Salmonella}

Salmonella is one of the main bacteria affecting commercial poultry and the second (after Campylobacter) of the most important zoonotic foodborne pathogens. Salmonella infections in poultry can be grouped into three categories: (1) Host-specific infections caused by nonmotile serotypes: Salmonella enterica subspecies enterica serovar Pullorum (S. Pullorum), Salmonella enterica subspecies enterica serovar Gallinarum (S. Gallinarum). Salmonella Pullorum causes pullorum disease (PD), an acute systemic disease of young birds. The infected adults are usually asymptomatic carriers. Salmonella Gallinarum causes fowl typhoid (FT) an acute or chronic septicemic disease that most often affects growing or mature birds. (2) Non-host-specific infections caused by motile serotypes referred as paratyphoid (PT) salmonellae: Salmonella enterica subspecies enterica serovar Enteritidis (S. Enteritidis), Salmonella enterica subspecies enterica serovar Typhimurium (S. Typhimurium). Other serotypes in 
poultry are i.a. S. Hadar, S. Infantis, S. Virchoff, $S$. Heidelberg, S. Kentucky, S. Anatum. Although PT infections occur frequently in poultry, they rarely cause acute systemic disease except in highly susceptible young birds under stressful conditions. Signs usually are seen only in young birds (less than four weeks of age). More often PT infections of poultry are characterized by asymptomatic and sometimes persistent colonization of the intestinal tract and internal organs, potentially leading to contamination of finished carcasses. (3) Avian arizonosis (AA) caused by Salmonella enterica subspecies arizonae (S. arizonae) is an acute or chronic disease of primarily young turkey poults. Adult birds generally show no clinical signs of disease but can be carriers [41].

Most human salmonellosis cases in the EU were induced by $S$. Enteritidis, and the proportion of human cases due this serovar was in 2018 at the same level as in 2018 as in 2017 (20.1 cases per 100,000 inhabitants). Similar to previous years, in 2018, Salmonella food-borne outbreaks were mostly caused by eggs and egg products. In food, the highest levels of Salmonella-positive samples were found in poultry meat. The EU flock prevalence of target Salmonella serovars in breeding hens, laying hens, broilers, and fattening turkeys decreased in recent years but stalled in breeding turkeys [18].

In the early 90s, Berchieri et al. [42] showed the efficacy of bacteriophages after simultaneous oral inoculation of chickens with phages and Salmonella enterica subspecies enterica serovar Typhimurium (S. Typhimurium). Bacteriophages reduced the viable numbers of Salmonella in the gut of chicken (crop, small intestine, cecum) during the experiment. Reductions of more than one $\log _{10}$ were seen in the crop and small intestine soon after inoculation and throughout the alimentary tract at three days post-inoculation. However, despite the phage multiplication, some phages (AB2) did not affect the number of Salmonella in cecum. No neutralizing antibodies to the phage were detected in the serum of chickens (at $32 \mathrm{dpi}$ ). Additionally, phages could be isolated from the in-contact birds.

Other reports confirmed that a bacteriophage cocktail composed of several phages was more effective in promoting the lysis of Salmonella spp. than a phage alone. In addition, the cocktail obtained from Salmonella enterica subsp. enterica serovar Enteritidis (S. Enteritidis), and serovar Typhimurium (S. Typhimurium), was also able to promote the lysis of other Salmonella serovars (Virchow, Hadar, Infantis). It seems that the significant reduction of Salmonella cell numbers in chicken cecum may be achieved after repeated treatment (oral re-administration) with the bacteriophage cocktail [43].

Other authors showed that bacteriophages might be effective alternatives to antibiotics to control fowl typhoid disease (Salmonella Gallinarum) in layer chickens. Chickens were orally fed with bacteriophages for seven days before the bacterial challenge and 21 days after the challenge. Bacterial re-isolation from the organs and mortality decreased significantly in the challenged chicken treated with the bacteriophages. The bacterial re-isolation rate and mortality were also lower in the contact chicken with phage treatment but not challenged with Salmonella. They were exposed to infection only by bacterial transmission from the closely housed challenged chickens. However, the bacterial re-isolation rate from the contact chickens without phage treatment was lower than from the challenged chicken [44].

Other studies reported the presence of Salmonella-specific bacteriophages in both sewage samples from poultry farms and infected broiler chickens. Bacteriophages from sewage water were administrated orally to chicks before oral Salmonella infections followed by 4 successive phage treatments after the bacterial challenge. No bacteria were detected in the cecum after the last (5th) dose, indicating that the chicks treated with phages were cured of Salmonella (at 15 dpi) [45].

Other authors have announced the complete genome sequence of bacteriophage isolated from water by using Salmonella enterica subspecies enterica serovar Enteritidis (S. Enteritidis). The bacteriophage can infect both $C$. jejuni and $S$. Enteritidis and can be used in phage therapy in poultry and to improve the biosafety of poultry meat [46].

Several bacteriophage products against Salmonella infections are available today [15,16]. In 2019, the first results were presented from the use of Salmonella phages at a large scale in a poultry production system [26]. The multiple administration of a bacteriophage mixture (SalmoFREE ${ }^{\circledR}$ ) in drinking water was safe, and did not affect the behavior of chicken nor their production parameters. At the end of 
the cycle (day 33), Salmonella was reduced in cloacal swabs to $0 \%$. Other product, Bafasal ${ }^{\circledR}$ (Proteon Pharmaceuticals, Poland) is a feed additive intended for birds and administered with drinking water (Table 1). In trials and commercial usage, Bafasal ${ }^{\circledR}$ has been shown to have a strong impact on food safety, reducing Salmonella levels as much as 200 times, while also improving feed conversion rate and reducing mortality. Bafasal ${ }^{\circledR}$ has both a prophylactic and a post-infection interventional effect, while its administration does not require the waiting period for meat and eggs [19]. Another product, Biotector $S 1^{\circledR}$ (CJ CheilJedangResearch Institute of Biotechnology, Seoul, South Korea), is the world's first bacteriophage product, which can be used as a feed additive to control Salmonella enterica subspecies enterica serovar Pullorum (S. Pullorum), and Salmonella enterica subspecies enterica serovar Gallinarum (S. Gallinarum) in poultry (Table 1 ). The mortality rate recorded in three experimental groups of commercial broilers (5-week-old Ross), which received Biotector $S 1^{\circledR}$ in different concentrations in feed $\left(5 \times 10^{7}, 1 \times 10^{8}\right.$ and $\left.2 \times 10^{8} \mathrm{PFU} / \mathrm{kg}\right)$, decreased by $73 \%$ in comparison to the control group (11.81\%) after the challenge. There were no significant differences in mortality between the experimental groups $(2.78 \%, 3.13 \%, 3.13 \%)$. In the group of broiler breeders (67-week-old Ross) receiving bacteriophages $\left(1 \times 10^{6} \mathrm{PFU} / \mathrm{kg}\right)$, the mortality rate $(45 \%)$ decreased by $53 \%$ when compared with the non-phage treated control (85\%) after challenge. The highest drop of mortality (by $86 \%$ ) was observed in layers (6-week-old Lohmann Brown) which received the same dose $\left(1 \times 10^{6} \mathrm{PFU} / \mathrm{kg}\right)$ before the challenge. The mortality in control group after challenge was 35\%. In the Hy-Line Brown layers, also performance was improved in the phage treated group $\left(1 \times 10^{8} \mathrm{PFU} / \mathrm{kg}\right): 3 \%$ increase in egg production (trial $90.6 \%$, control 87.5\%), and 2.4\% increase in egg mass (g/day/bird) (trial 59.2\%, control 56.8\%) [47].

\subsection{Escherichia coli}

Escherichia coli is a Gram-negative bacillus, a normal inhabitant of the digestive tract of birds, which is widely disseminated with feces. Most strains are nonpathogenic, however, certain pathogenic serotypes (avian pathogenic Escherichia coli-APEC) may induce disease, leading to mortality and condemnations. This opportunistic pathogen can act as both a primary and secondary pathogen. E. coli-associated infections are widely distributed among poultry of all ages and categories. Some strains, such as, enterohemorrhagic E. coli (EHEC), and its subgroup of Shiga toxin (Stx)-producing E. coli (STEC), are food-borne pathogens responsible for serious human diseases worldwide [48].

Bacteriophages infecting E. coli are called coliphages. The phage-based products intended for treatment colibacillosis in poultry are still not available on the market.

In a study of Barrow et al. [49], bacteriophage R, originally derived from human sewage, was effective in preventing and treating septicemia and cerebritis or meningitis in chickens. Chickens were inoculated intramuscularly or intracranially with E. coli, whereas phage preparations were administered by intramuscular injection (gastrocnemius muscle, right leg). An almost 100\% mortality rate was noted in the non-treated 3-week-old and newly hatched chickens inoculated by both routes. Phages reached the brain in chicken, which were earlier intracranially infected with E. coli. They were able to multiply rapidly and decline the bacterial count. Moreover, the above authors demonstrated the ability of bacteriophage to protect chickens even when the preparation was administered (1-2 days) before being challenged with E. coli or during the onset of clinical signs. This may indicate that phages can persist long enough in the tissues and thus may be used in the treatment as well as in the prophylaxis of colibacillosis. Interestingly, the authors noted also that a commonly known virucidal disinfectant, Virkon ${ }^{\mathrm{TM}}$ (Antec International, Sudbury, United Kingdom), was very effective against the phage used, however, these observations need to be confirmed in the future research.

Huff et al. [8] have demonstrated that aerosol spray of bacteriophages administered to 7-day-old chickens prior to the triple challenge with E. coli can prevent airsacculitis caused by E. coli. On the other hand, the aerosol spray of bacteriophages was ineffective when administered after the chicken had been challenged with E. coli. The effectiveness of treatment with bacteriophage seems to be dependent on the circulating bacteriophage titers. In opposition to the intramuscular injection of bacteriophages, the aerosol spray could have induced only low bacteriophage levels in the blood 
and only a few chickens had detectable levels. Further results demonstrated that bacteriophage treatment was comparable to enrofloxacin treatment. Moreover, when bacteriophage and enrofloxacin were used in combination, their synergistic effect improved the efficacy of colibacillosis treatments. Combining the antibiotic with bacteriophage therapy may reduce the levels of antibiotics used in treating bacterial diseases.

Other authors compared the efficacy of the antibiotic (chloramphenicol class) and oral phage therapy (from sewage) against enteropathogenic E. coli in 20-day-old chickens [50]. In the second week, no diarrhea was found in the birds receiving phages, while there were $12.4 \%$ diarrhea rates in the birds receiving antibiotic and $25.2 \%$ in the control group (treated with water). The death rate was $14.8 \%$ in the control group, which was 2-times and 5-times more than in the antibiotic and phage group, respectively. The authors concluded that phage was safe, non-toxic, and caused no disease in the chickens when compared with antibiotic treatments. Moreover, the chickens receiving phage had increased weight. The phage treatment had high specificity without affecting beneficial bacteria, which is very important for maintaining a favorable intestinal microecological homeostasis.

More recently, Tawakol et al. [51] showed that bacteriophage treatment (by intratracheal inoculation) reduced the severity and prevented the mortality of not only single APEC infection but also a mixed infection with APEC and infectious bronchitis virus (IBV). Additionally, in the mixed infection group, but not the single IBV infected group, the bacteriophage treatment significantly reduced the count of pathogenicity-shedding E. coli as well as IBV.

\subsection{Staphylococcus Aureus}

Staphylococcus aureus is considered as the most common and pathogenic staphylococcal species isolated from poultry. It should be mentioned that staphylococci (including S. aureus) belong to the normal inhabitants of skin, mucous membranes of healthy birds and are ubiquitous in the poultry environment. Staphylococcal infections caused by S. aureus are a worldwide problem in chicken and turkey production and cause economic losses due to decreased production results as well as mortality and condemnation of carcasses at slaughter. Diseases caused by S. aureus infections include arthritis, synovitis, chondronecrosis, osteomyelitis, gangrenous dermatitis, subdermal abscesses (bumblefoot), green liver-osteomyelitis complex in turkey, and septicemia [52]. Some enterotoxin-producing strains can cause food poisoning in people. Poultry-associated food poisoning can occur due to the contamination of carcasses with $S$. aureus at processing (especially enterotoxin-producing strains). Methicillin-resistant $S$. aureus (MRSA) found in poultry meat may raise concerns as well [53].

The phage which attacks bacteria Staphylococcus bacteria is called a staphylophage. Based on the genome size, staphylophages were grouped into three classes: class I-Podoviridae (with the smallest genome), class II-Siphoviridae (intermediate genome size), and class III-Myoviridae (the largest genome) [54]. Bacteriophages induced from S. aureus strains originating from broiler chickens and turkeys belonged to the family Siphoviridae of the order Caudovirales, and had an icosahedral head and a long, thin, non-contractile flexible tail, and double-stranded DNA. They belonged to 3 serogroups (A, $\mathrm{B}$, and $\mathrm{F}$ with $\mathrm{Fa}, \mathrm{Fb}$ subgroups) and exhibited strong lytic properties against Staphylococcus strains but also against other bacteria. Although bacteriophages showed strong specificity to S. aureus, some of them harbored the enterotoxigenic genes, which makes them useless in phage therapy [55]. From the therapeutic point of view, Myoviruses are considered the most interesting staphylococcal phages. Although podoviruses are strictly lytic they are very rare [54]. Today, there are no phage preparations intended for the prophylaxis and treatment of $S$. aureus-induced infections in poultry.

\subsection{Clostridium}

Clostridium perfringens is a Gram-positive anaerobic spore-forming non-motile rod-shaped bacterium. It is widespread in the natural environment and a normal inhabitant of the intestinal microbiota of poultry. At low population levels $\left(<10^{4} \mathrm{CFU}\right)$, it is non-pathogenic, however, its pathogenicity is mainly associated with toxins. In poultry, Clostridium perfringens type A and type C 
producing toxins can induce necrotic enteritis (NE) which in its both forms (acute clinical and subclinical) represents one of the most economically significant poultry diseases. Moreover, enterotoxin-positive C. perfringens can cause foodborne diseases, whereas the infected poultry meat may be a source for human intoxications [56].

Bacteriophages induced from C. perfringens strain originating from poultry intestines, soil, sewage, and poultry processing drainage water were identified as members of the order Caudovirales in the family Siphoviridae and Podoviridae. Many strains of C. perfringens remained resistant to the phages. Additionally, the activity of phages seemed to be restricted to a specific isolate of this bacterium $[57,58]$. Some authors suggested that endolysin encoded by phages of $C$. perfringens may be especially useful for control of this bacterium. The results indicated that endolysin may be active against all tested strains of $C$. perfringens, although variation in the sensitivities of different strains is possible [59-61].

Miller et al. [62] reported the efficacy of bacteriophage (INT-401) in controlling necrotic enteritis (NE) caused by C. perfringens in broiler chickens. The phage treatment via drinking water or feed allowed not only to reduce the mortality rate but also to improve weight gain and feed conversion ratio (FCR) in the experimentally infected broiler chicken.

Other authors evaluated the combined effect of the phages and bacteriocin against C. perfringens [63]. They observed the synergetic effect of two lytic phages P4, A3 (10 8 PFU/mL) and a heat-, pH-stable bacteriocin of $S$. hyointestinalis against $C$. perfringens isolated from chickens and pigs. The combined treatments with phages and bacteriocin have significantly reduced the bacterial population (by $6.20 \log$ units) than treatment with the phage (by $1.36 \log$ units, phage P4; 4.41 log units, phage A3) or bacteriocin alone (by $3.8 \log$ units). The treatment with phage or bacteriocin alone resulted in instant bactericidal and bacteriostatic effects against $C$. perfringens, however, regeneration of $C$. perfringens was also observed. As the data revealed, combining the phages with bacteriocin may represent potential options for the control of C. perfringens.

\section{Reduction of Food Contaminations (Biocontrol)}

Decontamination is a complex problem involving the removal and neutralization (inactivation) of microorganisms in food products, which enables retarding their putrefactive and aging processes. Counteracting human infections involves mainly the elimination of bacteria from foods. Many methods are used to help improve the safety of foods, however, not all are appropriate for fresh meats and products, and their usage is limited, e.g., heat pasteurization, high pressure, radiation. Other methods, such as the use of organic acids (due to their low $\mathrm{pH}$ ), are effective, however the bactericidal activity to be induced requires high concentrations of acids which may have an impact on meat quality and visual appearance (texture, color, oxidative stability, $\mathrm{pH}$, etc.) [15]. The concept of reducing pathogens in food by using phages has mainly addressed raw and raw meat and ready-to eat (RTE) products, and also decontamination of carcasses [64]. Nowadays, there are some commercialized phage products against Listeria monocytogenes, Salmonella, Shigella, and E. coli that use phages as food biopreservation agents (Table 1).

Listeria monocytogenes poses a particular foodborne hazard because of the ability to grow and replicate at refrigeration temperatures. There has been an increasing trend of confirmed human listeriosis cases from 2014 to 2018 [18]. The United States Food and Drug Administration (U.S. FDA) and the U.S. Department of Agriculture (USDA) approved ListShield ${ }^{\mathrm{TM}}$ (formerly LMP-102, Intralytix Inc.Baltimore, USA) as a food additive for ready-to-eat meat and poultry products. ListShield ${ }^{\mathrm{TM}}$ is a mixture of six lytic bacteriophages that specifically target L. monocytogenes and can be applied directly on food. The manufacturer has claimed that ListShield ${ }^{\mathrm{TM}}$ does not affect the organoleptic quality of foods [29].

Another known bacteriophage-based product against L. monocytogenes called Listex ${ }^{\mathrm{TM}}$ contains a single phage P100 at a concentration of 2x10 11 PFU/mL. Bacteriophage P100 has been shown not to pose a health risk and to be non-toxic. Listex ${ }^{\mathrm{TM}}$ P100 received the GRAS (generally recognized as safe) status issued by the FDA in 2006 and was intended for raw and RTE foods at levels not to 
exceed $10^{9} \mathrm{PFU} / \mathrm{g}$, usually as a spraying or dipping suspension. EFSA issued a scientific opinion on Listex $^{\mathrm{TM}} \mathrm{P} 100$ and recommended undertaking more studies on its efficacy in naturally contaminated RTE foods [31,32].

According to Bigot et al. [65], the effectiveness of the phage treatment depends on the initial concentration of phages. In their experiment, L. monocytogenes and then phage stock suspension (FWLLm1) were applied in similar volumes onto the surface of the commercially available vacuum-packed RTE chicken breast roll. Chicken samples were then vacuum-packaged and incubated at 30 and $5{ }^{\circ} \mathrm{C}$. The number of L. monocytogenes decreased on a RTE vacuum-packed chicken samples tested at $5{ }^{\circ} \mathrm{C}$. However, at $30^{\circ} \mathrm{C}$ there was an immediate reduction in Listeria concentration but then re-growth occurred. This re-growth was prevented over 21 days of incubation. After 21 days, Listeria cells that had survived in the phage-treated samples may have commenced the re-growth. It should be underlined that the temperature of $30^{\circ} \mathrm{C}$ and duration of incubation were abnormal and deviant from typical food storage conditions. Moreover, the authors concluded that the rate of phage and host application should be reported per unit area instead of per unit weight (with an unspecified area being inoculated).

The most recent studies by Kim et al. [66] revealed the efficacy of the bacteriophage cocktail in reducing Salmonella enterica subspecies enterica serovar Enteritidis (S. Enteritidis) in raw chicken breast meat at refrigeration temperatures $\left(4^{\circ} \mathrm{C}\right)$. These four lytic phages were isolated from a river proximate to a duck farm. All belonged to the Myoviridae and Siphoviridae family and had a broad lytic effect on 96\% (24/25) of different serovars of Salmonella enterica subsp. enterica (S. Enteritidis, S. Typhimurium, S. Paratyphi A, S. San Diego, S. Typhi). Other studies showed the efficacy of a phage-based product called SalmoFresh ${ }^{\mathrm{TM}}$ (Intralytix Inc., USA) in reducing Salmonella on chicken breast fillets stored under aerobic and also modified atmosphere conditions $\left(95 \% \mathrm{CO}_{2} / 5 \% \mathrm{O}_{2}\right)$ [67].

Even the newest methods for food decontamination will, however, not replace the standard hygienic principles. Nevertheless, they offer solutions that would allow for taking greater care over food safety and for extending the shelf life of food products, which in turn can contribute to lesser food waste.

\section{Use of Bacteriophages as Disinfectants}

Various approaches have been proposed to reduce the numbers of bacteria associated with poultry facilities, e.g., legal regulations, strict biosecurity strategies, and specific conditions. Since the main source of poultry meat contamination was confirmed to be the flock, it is reasonable to suggest that bacteria-free meat could be achieved by reducing their prevalence at a farm level. In addition, an aerosol spray of poultry and litter in production facilities may help to prevent horizontal transmission of the pathogen. Bacteriophage-based products may be used as biosanitizers in hatcheries, farms, transport crates, poultry processing plants, and food contact surfaces. Moreover, bacteriophages, have been considered as effective in inhibiting biofilm formation and dispersion of mature biofilms produced by pathogenic bacteria on surfaces commonly found in the poultry industry. The material that the equipment elements are made of is also important. It has been shown that glass and stainless-steel materials significantly promoted biofilm formation by Salmonella spp. compared to polyvinyl chloride surface (PVC). Moreover, $S$. Enteritidis and $S$. Heidelberg had stronger biofilm-forming ability than other serovars tested [68].

The phage-based surface disinfectants, such as BacWash ${ }^{\mathrm{TM}}$ (OmniLytics Inc., USA), target Salmonella and can be applied as a wash, mist, or spray, and used directly on the live animals prior to slaughter. Similarly, Ecolicide PX ${ }^{\mathrm{TM}}$ (Intralytix) E. coli O157:H7 has been developed for the decontamination of the skin of live animals prior to slaughter [21]. Atterbury et al. [69] reported the efficacy of bacteriophage in reducing the number of recoverable Campylobacter jejuni cells on artificially contaminated skin of broiler chicken. Other authors assessed five phages from chicken feces, characterized and selected to be used as biosanitizer [70]. They compared the activity of a phage cocktail with chemical agents in reducing Salmonella Enteritidis on chicken skin. Skin samples were 
dipped in $100 \mathrm{~mL}$ of the phage cocktail at $10^{9} \mathrm{PFU} / \mathrm{mL}$ for $30 \mathrm{~min}$ and experimentally contaminated with $1 \times 10^{5} \mathrm{CFU} / \mathrm{cm}^{2}$ Salmonella. Authors have demonstrated that bacteriophages reduced $S$. Enteritidis loads on chicken skin at refrigeration temperature and short contact time. A similar level of Salmonella reduction (by an average of $1 \log \mathrm{CFU} / \mathrm{cm}^{2}$ ) was also obtained after using chemical agents.

El-Gohary et al. [71] demonstrated that the treatment of litter by spraying with a bacteriophage preparation targeting E. coli was a practical and efficacious tool to prevent colibacillosis in broiler chickens resulting from exposure to $E$. coli in the environment.

\section{Threats Arising from the Use of Bacteriophages in Poultry}

Each phage-based preparation intended for use in veterinary medicine of poultry, in poultry production, and poultry industry should, most of all, be safe and effective. Dosage and delivery route (including the preparation of standardized formulations), administration timing of phage-based products, as well as the concomitant use of other preparations (e.g., competitive exclusion) or vaccinations are also of the utmost significance. The persistence of bacteriophages in/on food may vary with each bacteriophage, and with the conditions of application (e.g., dose) and environmental factors (e.g., temperature). The refrigeration temperatures may enhance the persistence of bacteriophages on the surface of meat products [72].

The approval for the use of bacteriophages as feed additives or directly on RTE food has elicited controversies and discussions. Even though ample research on bacteriophage applications has provided many positive conclusions, there are still some disadvantages and unknowns [73]. Additionally, the narrow range of activity of phages might also be problematic in disease control and may restrict the number of types of infections for which such an approach may be appropriate [49].

Due to the specific ability to kill bacteria, only strong lytic phages with known nucleotide sequences should be used. Lysogenic phages incorporate their genetic material into the bacterial genome. Consequently, they may act as vehicles for horizontal gene transmission between bacteria, or animals or to humans via the food chain. Due to the advance in research, it seems feasible to understand the gene flow between phages and their hosts. Hence, it would also be possible to avoid potentially adverse bacteriophages or to re-design them into the ones that would be incapable of transferring undesirable traits or any other gene dissemination systems. Many authors used different phages in the same product, enlarging the lytic spectrum and delaying the occurrence of resistance to phages. It seems that a phage cocktail is required for effective phage therapy [17].

The efficacy of bacteriophages depends on, among others, their good adaptation to replication and survival in required conditions. To achieve their optimal efficacy, it seems advisable to improve methods of phage selection and their isolation from the host environment [64]. It is essential to find better systems for phage purification ensuring the appropriate removal of elements of bacterial origin. Phages should be apyrogenic and non-allergenic (sterility test, lack of residual endotoxin).

It is generally known that bacteriophages are immunogenic and able to elicit specific antibody humoral responses which might influence phage therapy in humans and animals including poultry [74-78]. Although no anti-phage antibodies were found in the first safety oral trial in humans [79], later studies indicated that phage therapy may induce various levels of antibodies which may not necessarily affect the outcome of therapy [80]. Other results suggest that the antiphage activity in human sera depends on the route of phage administration and phage type [76]. The phage-antibody interactions do not necessarily lead to phage inactivation. However, the various phages might differently respond to neutralization by antibodies. Interactions between phage and host's immune system are not well known. Some authors have recommended phages screening for their ability to avoid antibody neutralization [81]. Modern technological systems (e.g., phage encapsulation) have been developed to increase phage activity in treating intracellular infections and phage safety of those which are directly added to food products and animal feed [82]. 
The importance of the phage concentration applied has been also shown in the studies on phage therapy in chickens $\left(>10^{10} \mathrm{PFU} / \mathrm{mL}\right)$ and on RTE poultry products $\left(10^{7} \mathrm{PFU} / \mathrm{cm}^{2}\right)$. The presented data demonstrate that only high concentrations of phages are effective in ensuring a significant reduction in mortality and in foodborne pathogens $[42,65]$. On the other hand, the high doses and very long time of exposure may induce neutralizing antibodies. Moreover, the phages can accumulate in different organs. Żaczek et al. [80] found that phage dose, not the level of purification of phage preparation, plays an important role in immunogenicity of therapeutic phage preparations in humans. According to the literature phage formulations containing $10^{5}$ to $10^{11} \mathrm{PFU} /$ dose have been administered orally to humans [74]. It should be noted that most phages can be destroyed when exposed to low $\mathrm{pH}$ of the stomach. Currently, several GRAS approvals permit the application of phage preparation up to $10^{8} \mathrm{PFU} / \mathrm{g}$ of food $[15,22,23]$.

Many phage-based preparations have been commercialized and licensed for use in the United States, however, their implementation in the EU required more regulations and scientific opinions. Each phage should be assessed on a case-by-case basis for the nucleic acid sequence to demonstrate the impossibility of a lysogenic cycle and the absence of any potential virulence factors and/or antimicrobial resistance genes. The EFSA encouraged the research into specific bacteriophage-pathogen-food combinations to assess the issue of bacteriophage persistence in foods, and their ability to prevent recontamination with the bacterial pathogen [72].

Currently, there are no regulations or control methods aimed at monitoring bacteriophages and their consumption by humans [4]. Susceptibility of the bacteria to the phage as well as phage stability and efficiency should be monitored during the phage treatment. Moreover, scientific efforts should be undertaken to develop methods for preventing the spreading of phage resistant bacteria.

It seems that one of the challenges may be an economic aspect associated with phage large-scale production to cover the possible needs of the poultry market. Most recently, Torres-Acosta et al. [27] developed a bioprocess model and performed an economic analysis of different production scenarios for the scaled-up generation bacteriophage cocktail intended for the poultry industry. The best cost-effective results could be obtained when one bioreactor (156 liters) was used for six phages, then a $0.45 \mu \mathrm{m}$ filtration for removal of biomass, and a $0.22 \mu \mathrm{m}$ filtration for sterility. Based on experimental-theoretical data, the applied configuration could supply 210 million chickens and give 0.02 USD production costs per chicken. Results indicate that the production titer has a crucial impact on the subsequent decrease in production costs; therefore, this parameter which requires proper optimization and improvement.

\section{Conclusions}

Despite skepticism in bacteriophages application in the poultry industry, many studies indicated their efficacy and considered them to be a useful alternative to antibiotics in the age of multidrug resistance and in the growing tendency to moving towards the post-antibiotic era. Future investigations could focus on the specific phage-bacterium interactions, pharmacodynamics, and mechanisms of coevolution between phages and bacteria.

Author Contributions: The idea for the paper was conceived by all authors. K.Ż. and B.D., search of literature, writing and original draft preparation; K.Ż., M.M. and B.D., review and editing of the manuscript; B.D., supervision and the final version of the manuscript. All authors have read and agreed to the final published version of the manuscript.

Funding: This research received no special or external funding. The costs of manuscript publication were funded by Institute of Animal Sciences, Warsaw University of Life Sciences-SGGW, Ciszewskiego 8 St., 02-786 Warsaw, Poland.

Conflicts of Interest: The authors declare no conflict of interest. 


\section{References}

1. Twort, F.W. An investigation on the nature of ultramicroscopic viruses. Lancet 1915, 186, 1241-1243. [CrossRef]

2. d'Hérelle, F. Sur un microbe invisible antagoniste des bacilles dysentériques. Crit. Rev. Acad. Sci. Paris 1917, 165,373 .

3. Duckworth, D.H. Who Discovered Bacteriophage? Bacteriol. Rev. 1976, 40, 793-802. [CrossRef] [PubMed]

4. Gómez-Gómez, C.; Blanco-Picazo, P.; Brown-Jaque, M.; Quirós, P.; Rodríguez-Rubio, L.; Cerdà-Cuellar, M.; Muniesa, M. Infectious phage particles packaging antibiotic resistance genes found in meat products and chicken feces. Sci. Rep. 2019, 9, 13281. [CrossRef] [PubMed]

5. Manrique, P.; Bolduc, B.; Walk, S.T.; van der Oost, J.; de Vos, W.M.; Young, M.J. Healthy human gut phageome. Proc. Natl. Acad. Sci. USA 2016, 113, 10400-10405. [CrossRef] [PubMed]

6. Ackermann, H.W. Bacteriophage observations and evolution. Res. Microbiol. 2003, 154, 245-251. [CrossRef]

7. Wommack, K.E.; Hill, R.T.; Kessel, M.; Russek-Cohen, E.; Colwell, R.R. Distribution of viruses in the Chesapeake Bay. Appl. Environ. Microbiol. 1992, 58, 2965-2970. [CrossRef]

8. Huff, G.R.; Huff, W.E.; Rath, N.C.; Donoghue, A.M. Critical Evaluation of Bacteriophage to Prevent and Treat Colibacillosis in Poultry. JAAS 2009, 63, 93-98.

9. Fortier, L.C.; Sekulovic, O. Importance of prophages to evolution and virulence of bacterial pathogens. Virulence 2013, 4, 354-365. [CrossRef]

10. O'Flaherty, S.; Ross, R.P.; Coffey, A. Bacteriophage and their lysins for elimination of infectious bacteria. FEMS Microbiol. Rev. 2009, 33, 801-819. [CrossRef]

11. Kazi, M.; Annapure, U.S. Bacteriophage biocontrol of foodborne pathogen. J. Food Sci. Technol. 2016, 53, 1355-1362. [CrossRef] [PubMed]

12. Fernandes, S.; Proença, D.; Cantante, C.; Silva, F.A.; Leandro, C.; Lourenço, S.; Milheiriço, C.; de Lencastre, H.; Cavaco-Silva, P.; Pimentel, M.; et al. Novel chimerical endolysins with broad antimicrobial activity against methicillin-resistant Staphylococcus aureus. Microb. Drug Resist. 2012, 18, 333-343. [CrossRef] [PubMed]

13. Kirbis, A.; Krizmana, M. Spread of antibiotic resistant bacteria from food of animal origin to humans and vice versa. Procedia Food Sci. 2015, 5, 148-151. [CrossRef]

14. Lin, D.M.; Koskella, B.; Lin, H.C. Phage therapy: An alternative to antibiotics in the age of multi-drug resistance. World J. Gastrointest Pharmacol. Ther. 2017, 8, 162-173. [CrossRef] [PubMed]

15. Moye, Z.D.; Woolston, J.; Sulakvelidze, A. Bacteriophage Applications for Food Production and Processing. Viruses 2018, 10, 205. [CrossRef] [PubMed]

16. Monk, A.B.; Rees, C.D.; Barrow, P.; Hagens, S.; Harper, D.R. Bacteriophage applications: Where are we now? Lett. Appl. Microbiol. 2010, 51,363-369. [CrossRef]

17. Wernicki, A.; Nowaczek, A.; Urban-Chmiel, R. Bacteriophage therapy to combat bacterial infections in poultry. Virol. J. 2017, 14, 179. [CrossRef]

18. EFSA and ECDC (European Food Safety Authority and European Centre for Disease Prevention and Control): The European Union One Health 2018 Zoonoses Report. EFSA J. 2019, 17, 1-276. [CrossRef]

19. Wójcik, E.A.; Wojtasik, A.; Górecka, E.; Stańczyk, M.; Dastych, J. Application of bacteriophage preparation BAFASAL ${ }^{\circledR}$ in broiler chickens experimentally exposed to Salmonella spp. SSRCI Vet. Med. Prod. Feed Add. 2015, 16, 241-251.

20. Proteon-Pharmaceuticals. Bafasal ${ }^{\circledR}$. Available online: https://www.proteonpharma.com/products/bafasalpoultry/ (accessed on 4 April 2020).

21. Sommer, J.; Trautner, C.; Witte, A.K.; Fister, S.; Schoder, D.; Rossmanith, P.; Mester, P.J. Don't Shut the Stable Door after the Phage Has Bolted-The Importance of Bacteriophage Inactivation in Food Environments. Viruses 2019, 11, 468. [CrossRef]

22. Phagelux Inc. SalmoPro ${ }^{\circledR}$. Available online: https://www.fda.gov/media/95017/download (accessed on 4 April 2020).

23. Micreos Food Safety BV. Salmonelex ${ }^{\mathrm{TM}}$. Available online: https://www.fda.gov/media/98485/download (accessed on 4 April 2020).

24. Micreos Food Safety BV. PhageGuard S. Available online: https://www.micreos.com/content/contact.aspx (accessed on 4 April 2020).

25. Sillankorva, S.M.; Oliveira, H.; Azeredo, J. Bacteriophages and their role in food safety. Int. J. Microbiol. 2012, 2012, 863945. [CrossRef] [PubMed] 
26. Clavijo, V.; Baquero, D.; Hernandez, S.; Farfan, J.C.; Arias, J.; Arévalo, A.; Donado-Godoy, P.; Vives-Flores, M. Phage cocktail SalmoFREE ${ }^{\circledR}$ reduces Salmonella on a commercial broiler farm. Poult. Sci. 2019, 98, 5054-5063. [CrossRef] [PubMed]

27. Torres-Acosta, M.A.; Clavijo, V.; Vaglio, C.; González-Barrios, A.F.; Vives-Flórez, M.J.; Rito-Palomares, M. Economic evaluation of the development of a phage therapy product for the control of Salmonella in poultry. Biotechnol. Prog. 2019, 35, e2852. [CrossRef] [PubMed]

28. Intralytix Inc. Bacteriophage Products-Food Safety Products. Available online: http://www.intralytix.com/ index.php?page=prod (accessed on 4 April 2020).

29. Perera, M.N.; Abuladze, T.; Li, M.; Woolston, J.; Sulakvelidze, A. Bacteriophage cocktail significantly reduces or eliminates Listeria monocytogenes contamination on lettuce, apples, cheese, smoked salmon and frozen foods. Food. Microbiol. 2015, 52, 42-48. [CrossRef]

30. Micreos Food Safety BV. Listex ${ }^{\mathrm{TM}}$ P100. Available online: https://phageguard.com/wp-content/uploads/2020/ 02/2020-02-11-PhageGuard-Application-Data-Sheet-RTE-.pdf (accessed on 4 April 2020).

31. Soni, K.A.; Nannapaneni, R.; Hagens, S. Reduction of Listeria monocytogenes on the surface of fresh channel catfish fillets by bacteriophage Listex P100. Foodborne Pathog. Dis. 2010, 7, 427-434. [CrossRef]

32. EFSA BIOHAZ Panel (EFSA Panel on Biological Hazards): Scientific opinion on the evaluation of the safety and efficacy of ListexTM P100 for reduction of pathogens on different ready-to-eat (RTE) food products. EFSA J. 2016, 14, 1-94. [CrossRef]

33. Sahin, O.; Kassem, I.I.; Shen, Z.; Lin, J.; Rajashekara, G.; Zhang, Q. Campylobacter in Poultry: Ecology and Potential Interventions. Avian Dis. 2015, 59, 185-200. [CrossRef] [PubMed]

34. Wysok, B.; Pastuszczak-Frąk, M.; Uradziński, J.; Gomółka-Pawlicka, M.; Dzisko, J.; Dziedziech, M.; Marko, A. Występowanie i antybiotykooporność szczepów Campylobacter spp. wyizolowanych od zwierząt rzeźnych i ludzi. Med. Weter. Vet. Med. Sci. Prac. 2015, 71, 801-806.

35. Nowaczek, A.; Urban-Chmiel, R.; Dec, M.; Puchalski, A.; Stẹpień-Pyśniak, D.; Marek, A.; Pyzik, E. Campylobacter spp. and bacteriophages from broiler chickens: Characterization of antibiotic susceptibility profiles and lytic bacteriophages. MicrobiologyOpen 2019, 8, e784. [CrossRef] [PubMed]

36. Marotta, F.; Garofolo, G.; Di Donato, G.; Aprea, G.; Platone, I.; Cianciavicchia, S.; Alessiani, A.; Di Giannatale, E. Population diversity of Campylobacter jejuni in poultry and its dynamic of contamination in chicken meat. Biomed Res. Int. 2015, 2015, 859845. [CrossRef]

37. Atterbury, R.J.; Connerton, P.L.; Dodd, C.E.; Rees, C.E.; Connerton, I.F. Isolation and characterization of Campylobacter bacteriophages from retail poultry. Appl. Environ. Microbiol. 2003, 69, 4511-4518. [CrossRef] [PubMed]

38. Firlieyanti, A.S.; Connerton, P.L.; Connerton, I.F. Campylobacters and their bacteriophages from chicken liver: The prospect for phage biocontrol. Int. J. Food Microbiol. 2016, 237, 121-127. [CrossRef] [PubMed]

39. Richards, P.J.; Connerton, P.L.; Connerton, I.F. Phage Biocontrol of Campylobacter jejuni in Chickens Does Not Produce Collateral Effects on the Gut Microbiota. Front. Microbiol. 2019, 10, 476. [CrossRef]

40. Jäckel, C.; Hammerl, J.A.; Hertwig, S. Campylobacter Phage Isolation and Characterization: What We Have Learned So Far. Methods Protoc. 2019, 2, 18. [CrossRef]

41. Gast, R.K. Salmonella Infections. In Diseases of Poultry, 13th ed.; Swayne, D.E., Glisson, J.R., McDougald, L.R., Nolan, L.K., Suarez, D.L., Nair, V.L., Eds.; Wiley-Blackwell: Ames, IA, USA, 2013; pp. 677-736.

42. Berchieri, A.; Lovell, M.A.; Barrow, P.A. The activity in the chicken alimentary tract of bacteriophages lytic for Salmonella typhimurium. Res. Microbiol. 1991, 142, 541-549. [CrossRef]

43. Bardina, C.; Spricigo, D.A.; Cortés, P.; Llagostera, M. Significance of the bacteriophage treatment schedule in reducing Salmonella colonization of poultry. Appl. Environ. Microbiol. 2012, 78, 6600-6607. [CrossRef]

44. Hong, S.S.; Jeong, J.; Lee, J.; Kim, S.; Min, W.; Myung, H. Therapeutic effects of bacteriophages against Salmonella gallinarum infection in chickens. J. Microbiol. Biotechnol. 2013, 23, 1478-1483. [CrossRef]

45. Nabil, N.M.; Tawakol, M.M.; Hassan, H.M. Assessing the impact of bacteriophages in the treatment of Salmonella in broiler chickens. Infect. Ecol. Epidemiol. 2018, 8, 1539056. [CrossRef]

46. Lee, S.; Kwon, T.; Chae, S.J.; Kim, J.H.; Kang, Y.H.; Chung, G.T.; Kim, D.W.; Lee, D.Y. Complete Genome Sequence of Bacteriophage MA12, Which Infects both Campylobacter jejuni and Salmonella enterica Serovar Enteritidis. Genome Announc. 2016, 4, e00810-e00816. [CrossRef] 
47. Kim, J.-W.; Cho, Y.-W.; Im, H.-J.; Shin, E.-M.; Seo, H.-S.; Bae, G.-D.; Son, B.-K.; Yang, S.-Y. Bacteriophages: The Alternatives to Antibiotics for Animal Feeds. In International Symposium: Alternatives to Antibiotisc (ATA) Challenges and Solutions in Animal Production; OIE: Paris, France, 2012. Available online: https://www.ars. usda.gov/alternativestoantibiotics/PDF/IABS\%20Abstracts\%20Book.pdf (accessed on 7 April 2020).

48. Nolan, L.K.; Barnes, H.J.; Vaillancourt, J.-P.; Abdul-Aziz, T.; Logue, C.M. Colibacillosis. In Diseases of Poultry, 13th ed.; Swayne, D.E., Glisson, J.R., McDougald, L.R., Nolan, L.K., Suarez, D.L., Nair, V.L., Eds.; Wiley-Blackwell: Ames, IA, USA, 2013; pp. 751-805.

49. Barrow, P.; Lovell, M.; Berchieri, A., Jr. Use of lytic bacteriophage for control of experimental Escherichia coli septicemia and meningitis in chickens and calves. Clin. Diagn. Lab. Immunol. 1998, 5, 294-298. [CrossRef]

50. Xie, H.; Zhuang, X.; Kong, J.; Ma, G.; Zhang, H. Bacteriophage Esc-A is an efficient therapy for Escherichia coli 3-1 caused diarrhea in chickens. J. Gen. Appl. Microbiol. 2005, 51, 159-163. [CrossRef] [PubMed]

51. Tawakol, M.M.; Nabil, N.M.; Samy, A. Evaluation of bacteriophage efficacy in reducing the impact of single and mixed infections with Escherichia coli and infectious bronchitis in chickens. Infect. Ecol. Epidemiol. 2019, 9, 1686822. [CrossRef] [PubMed]

52. Andreasen, C.B. Staphylococcosis. In Diseases of Poultry, 13th ed.; Swayne, D.E., Glisson, J.R., McDougald, L.R., Nolan, L.K., Suarez, D.L., Nair, V.L., Eds.; Wiley-Blackwell: Ames, IA, USA, 2013; pp. 971-977.

53. Feßler, A.T.; Kadlec, K.; Hassel, M.; Hauschild, T.; Eidam, C.; Ehricht, R.; Monecke, S.; Schwarz, S. Characterization of Methicillin-Resistant Staphylococcus aureus Isolates from Food and Food Products of Poultry Origin in Germany. Appl. Environ. Microbiol. 2011, 77, 7151-7157. [CrossRef]

54. Leskinen, K.; Tuomala, H.; Wicklund, A.; Horsma-Heikkinen, J.; Kuusela, P.; Skurnik, M.; Kiljunen, S. Characterization of vB_SauM-fRuSau02, a Twort-Like Bacteriophage Isolated from a Therapeutic Phage Cocktail. Viruses 2017, 9, 258. [CrossRef]

55. Marek, A.; Pyzik, E.; Stępień-Pyśniak, D.; Urban-Chmiel, R.; Nowaczek, A. Characterization of bacteriophages and their carriage in Staphylococcus aureus isolated from broilers in Poland. Br. Poult. Sci. 2019, 60, 373-380. [CrossRef]

56. Van Immerseel, F.; De Buck, J.; Pasmans, F.; Huyghebaert, G.; Haesebrouck, F.; Ducatelle, R. Clostridium perfringens in poultry: An emerging threat for animal and public health. Avian Pathol. 2004, 33, 537-549. [CrossRef]

57. Smith, H.W. The bacteriophages of Clostridium perfringens. J. Gen. Microbiol. 1959, 21, 622-630. [CrossRef]

58. Seal, B.S. Characterization of bacteriophages virulent for Clostridium perfringens and identification of phage lytic enzymes as alternatives to antibiotics for potential control of the bacterium. Poult. Sci. 2013, 92, 526-533. [CrossRef]

59. Zimmer, M.; Vukov, N.; Scherer, S.; Loessner, M.J. The murein hydrolase of the bacteriophage phi3626 dual lysis system is active against all tested Clostridium perfringens strains. Appl. Environ. Microbiol. 2002, 68, 5311-5317. [CrossRef]

60. Nariya, H.; Miyata, S.; Tamai, E.; Sekiya, H.; Maki, J.; Okabe, A. Identification and characterization of a putative endolysin encoded by episomal phage phiSM101 of Clostridium perfringens. Appl. Microbiol. Biotechnol. 2011, 90, 1973-1979. [CrossRef]

61. Gervasi, T.; Horn, N.; Wegmann, U.; Dugo, G.; Narbad, A.; Mayer, M.J. Expression and delivery of an endolysin to combat Clostridium perfringens. Appl. Microbiol. Biotechnol. 2014, 98, 2495-2505. [CrossRef] [PubMed]

62. Miller, R.W.; Skinner, J.; Sulakvelidze, A.; Mathis, G.F.; Hofacre, C.L. Bacteriophage therapy for control of necrotic enteritis of broilerchickens experimentally infected with Clostridium perfringens. Avian Dis. 2010, 54, 33-40. [CrossRef] [PubMed]

63. Heo, S.; Kim, M.G.; Kwon, M.; Lee, H.S.; Kim, G.B. Inhibition of Clostridium perfringens using Bacteriophages and Bacteriocin Producing Strains. Korean J. Food Sci. Anim. Resour. 2018, 38, 88-98. [CrossRef] [PubMed]

64. García, P.; Martínez, B.; Obeso, J.M.; Rodríguez, A. Bacteriophages and their application in food safety. Lett. Appl. Microbiol. 2008, 47, 479-485. [CrossRef]

65. Bigot, B.; Lee, W.J.; McIntyre, L.; Wilson, T.; Hudson, J.A.; Billington, C.; Heinemann, J.A. Control of Listeria monocytogenes growth in a ready-to-eat poultry product using a bacteriophage. Food Microbiol. 2011, 28, 1448-1452. [CrossRef] [PubMed] 
66. Kim, J.H.; Kim, H.J.; Jung, S.J.; Mizan, M.F.R.; Park, S.H.; Ha, S.D. Characterization of Salmonella spp.-specific bacteriophages and their biocontrol application in chicken breast meat. J. Food Sci. 2020, 85, 526-534. [CrossRef]

67. Sukumaran, A.T.; Nannapaneni, R.; Kiess, A.; Sharma, C.S. Reduction of Salmonella on chicken breast fillets stored under aerobic or modified atmosphere packaging by the application of lytic bacteriophage preparation SalmoFresh ${ }^{\mathrm{TM}}$. Poult. Sci. 2016, 95, 668-675. [CrossRef]

68. Garcia, K.C.O.D.; Corrêa, I.M.O.; Pereira, L.Q.; Silva, T.M.; Mioni, M.S.R.; Izidoro, A.C.M.; Bastos, I.H.V.; Gonçalves, G.A.M.; Okamoto, A.S.; Andreatti Filho, R.L. Bacteriophage use to control Salmonella biofilm on surfaces present in chicken slaughterhouses. Poult Sci. 2017, 96, 3392-3398. [CrossRef]

69. Atterbury, R.J.; Connerton, P.L.; Dodd, C.E.; Rees, C.E.; Connerton, I.F. Application of host-specific bacteriophages to the surface of chicken skin leads to a reduction in recovery of Campylobacter jejuni. Appl. Environ. Microbiol. 2003, 69, 6302-6306. [CrossRef]

70. Hungaro, H.M.; Mendonça, R.C.S.; Gouvêa, D.M.; Vanetti, M.C.D.; Pinto, C.L.D. Use of bacteriophages to reduce Salmonella in chicken skin in comparison with chemical agents. Food Res. Int. 2013, 52, 75-81. [CrossRef]

71. El-Gohary, F.A.; Huff, W.E.; Huff, G.R.; Rath, N.C.; Zhou, Z.Y.; Donoghue, A.M. Environmental augmentation with bacteriophage prevents colibacillosis in broiler chickens. Poult Sci. 2014, 93, 2788-2792. [CrossRef] [PubMed]

72. EFSA Panel on Biological Hazards (BIOHAZ): Scientific Opinion on the maintenance of the list of QPS microorganisms intentionally added to food or feed (2009 update). EFSA J. 2009, 7, 1-92.

73. Loc-Carrillo, C.; Abedon, S.T. Pros and cons of phage therapy. Bacteriophage. 2011, 1, 111-114. [CrossRef] [PubMed]

74. Sulakvelidze, A.; Alavidze, Z.; Morris, J.G., Jr. Bacteriophage therapy. Antimicrob. Agents Chemother. 2001, 45, 649-659. [CrossRef] [PubMed]

75. Huff, W.E.; Huff, G.R.; Rath, N.C.; Donoghue, A.M. Immune interference of bacteriophage efficacy when treating colibacillosis in poultry. Poult. Sci. 2010, 89, 895-900. [CrossRef] [PubMed]

76. Łusiak-Szelachowska, M.; Zaczek, M.; Weber-Dąbrowska, B.; Międzybrodzki, R.; Kłak, M.; Fortuna, W.; Letkiewicz, S.; Rogóż, P.; Szufnarowski, K.; Jończyk-Matysiak, E.; et al. Phage neutralization by sera of patients receiving phage therapy. Viral Immunol. 2014, 27, 295-304. [CrossRef]

77. Cisek, A.A.; Dabrowska, I.; Gregorczyk, K.P.; Wyżewski, Z. Phage Therapy in Bacterial Infections Treatment: One Hundred Years After the Discovery of Bacteriophages. Curr. Microbiol. 2017, 74, 277-283. [CrossRef]

78. Majewska, J.; Kaźmierczak, Z.; Lahutta, K.; Lecion, D.; Szymczak, A.; Miernikiewicz, P.; Drapała, J.; Harhala, M.; Marek-Bukowiec, K.; Jędruchniewicz, N.; et al. Induction of Phage-Specific Antibodies by Two Therapeutic Staphylococcal Bacteriophages Administered per os. Front. Immunol. 2019, 10, 2607. [CrossRef]

79. Bruttin, A.; Brüssow, H. Human volunteers receiving Escherichia coli phage T4 orally: A safety test of phage therapy. Antimicrob. Agents Chemother. 2005, 49, 2874-2878. [CrossRef]

80. Żaczek, M.; Łusiak-Szelachowska, M.; Jończyk-Matysiak, E.; Weber-Dabrowska, B.; Międzybrodzki, R.; Owczarek, B.; Kopciuch, A.; Fortuna, W.; Rogóż, P.; Górski, A. Antibody Production in Response to Staphylococcal MS-1 Phage Cocktail in Patients Undergoing Phage Therapy. Front. Microbiol. 2016, 7, 1681. [CrossRef]

81. Naghizadeh, M.; Karimi Torshizi, M.A.; Rahimi, S.; Engberg, R.M.; Sørensen Dalgaard, T. Effect of serum anti-phage activity on colibacillosis control by repeated phage therapy in broilers. Vet. Microbiol. 2019, 234, 61-71. [CrossRef] [PubMed]

82. Choińska-Pulita, A.; Mituła, P.; Śliwka, P.; Łaba, W.; Skaradzińska, A. Bacteriophage encapsulation: Trends and potential applications. Trends Food Sci. Technol. 2015, 45, 212-221. [CrossRef]

(C) 2020 by the authors. Licensee MDPI, Basel, Switzerland. This article is an open access article distributed under the terms and conditions of the Creative Commons Attribution (CC BY) license (http://creativecommons.org/licenses/by/4.0/). 